Ann. Zootech., 1980, 29, no h. s., 161-171.

\title{
Protein utilisation \\ The basis of feeding standards for protein in growing and fattening beef cattle
}

\author{
J.H.B. ROY \\ National Institute for Research in Dairying, Shinfield, Reading (UK)
}

\begin{abstract}
The historical background to protein feeding standards in the UK and the shortcomings of digestible crude protein and available protein as standards for the future are considered. The proposed ARC protein system, which takes into account contributions from microbial protein and dietary protein undegraded in the rumen, and the derivation of the three linear equations necessary for computation of the protein requirements is explained. The system is of particular value in predicting the situations in which non-protein $\mathrm{N}$ can be successfully used. The method of computing standards for the pre-ruminant calf is also presented, as well as some aspects of the contribution of microbial protein to tissue protein needs in relation to metabolisability of the gross energy of the diet and to breed size.
\end{abstract}

\section{Résumé \\ Bases des recommandations alimentaires en azote pour les bovins en croissance et à l'engrais}

L'auteur présente l'historique des recommandations azotées en Grande-Bretagne et souligne les insuffisances des matières azotées digestibles et des «protéines disponibles 》 comme bases des recommandations pour l'avenir. Le système proposé par l'ARC pour les recommandations azotées et l'origine des trois relations linéaires nécessaires pour les établir, sont expliqués : ce système tient compte des quantités respectives des protéines microbiennes et des protéines non dégradées dans le rumen. Ce système est particulièrement intéressant pour prévoir les rations dans lesquelles l'azote non protéique peut être bien utilisé. La méthode de calcul des recommandations en azote pour le veau préruminant est également expliquée. De même l'auteur développe certains aspects de la contribution des protéines microbiennes à la couverture des besoins protéiques des tissus en fonction de la teneur en énergie métabolisable de la ration et du format des animaux lié à leur race. 


\section{Historical background}

Since the end of the 19 th century, feeding standards for protein in the UK have been expressed in terms of apparently digestible crude protein $(\mathrm{N} \times 6.25)$. In 1925 (Ministry of Agriculture AND Fisheries, 1925) the "protein equivalent", the mean of the digestible crude and true protein concentration, was proposed for use in rationing of dairy cows, when root crops, silage and certain green fodders such as kale were included in the diet. Thus, non-protein nitrogen was assumed to be fully digestible, but to have only half the value of digestible true protein. In 1960, the "protein equivalent" was considered to underestimate the value of non-protein $\mathrm{N}$ of silages, and the use of digestible crude protein was advocated again for this class of feed (Evans, 1960).

RoY (1959) proposed standards of digestible crude protein for maintenance plus a weight gain of $0.45 \mathrm{~kg} / \mathrm{d}$ or of $0.9 \mathrm{~kg} / \mathrm{d}$ based on a review of the results of feeding trials and of the factorial method for calculating protein requirements (Mitchell, 1929). In particular, the results of BLAXTER and MiTCHELl (1948), BlaXter and WOOD (1951), LofGreEN et al. (1951), BRisson et al. (1957) and BAILEY and Broster (1957) were considered. These standards though somewhat empirical are still currently being used by the advisory service in the UK, in spite of the proposal in ARC (1965) that requirements should be expressed as "available protein".

The "available protein" requirement was defined as the amount of crude protein of a given biological value that would need to be absorbed from the digestive tract to supply the requirements of the tissues for maintenance and for a given level of production. It was calculated from the sum of the amount of $\mathrm{N}$ retained in the body and of the endogenous losses of $\mathrm{N}$ in the urine and in hair and scurf, divided by an average biological value of dietary $\mathrm{N}$. The gain in carcase $\mathrm{N}$ was considered to be $24 \mathrm{~g} / \mathrm{kg}$ liveweight gain based largely on the results of early work in the USA on carcase composition, whilst endogenous urinary $\mathrm{N}$ excretion was found to decrease from $0.20 \mathrm{~g} / \mathrm{kg}^{0.73}$ at $50 \mathrm{~kg}$ liveweight to $0.12 \mathrm{~g} / \mathrm{kg}^{0.73}$ at $200 \mathrm{~kg}$ liveweight or greater, corresponding to absolute values for loss of $\mathrm{N}$ varying from $3.4 \mathrm{~g} / \mathrm{d}$ at $50 \mathrm{~kg}$ liveweight to $12.8 \mathrm{~g}$ at $600 \mathrm{~kg}$ liveweight. The loss of $\mathrm{N}$ in hair and scurf was $0.02 \mathrm{~g} / \mathrm{kg}^{0.73}$ with absolute values varying from a loss of $0.3 \mathrm{~g} / \mathrm{d}$ at $50 \mathrm{~kg}$ liveweight to $2.1 \mathrm{~g} / \mathrm{d}$ at $600 \mathrm{~kg}$ liveweight.

Average biological values, a measure of the proportion of absorbed $\mathrm{N}$ that was retained, of 0.80 and 0.70 for pre-ruminant and ruminant cattle respectively were adopted. The wastage in this process, which resulted in exogenous urinary $\mathrm{N}$ excretion, was considered to be due in part to an imbalance in the absorbed amino acid composition in relation to the concominant demand of the tissues and in part to losses as a result of ammonia being absorbed from the rumen and excreted as urea. No attempt was made to assign a biological value to nonprotein $N$ (NPN) but it was considered that increased urinary losses from soluble sources of dietary NPN would result in a reduction in its value compared to that of protein $\mathrm{N}$.

The "available protein" requirements were tabulated and had the advantage of being independent of the value of any particular feed. However, to meet the "availage protein" requirements from a particular ration, the requirements had to be converted to apparently digestible crude protein, and this necessitated the 
use of values both for dry matter intake of the ration and for metabolic faecal $\mathrm{N}$ excretion. The latter was assumed to be $2.5 \mathrm{gN}$ and $5 \mathrm{gN} / \mathrm{kg}$ dry matter intake for pre-ruminant and ruminant cattle respectively.

\section{Shortcomings of standards based on digestible crude protein and available protein}

The concepts of available protein and digestible crude protein had a number of limitations :

1. Available protein assumed that faecal $\mathbf{N}$ could be divided into a component of indigestible feed $\mathrm{N}$ and into that which represented unabsorbed secretions of $\mathrm{N}$-containing compounds into the tract (metabolic faecal $\mathrm{N}$ ). However faecal $\mathbf{N}$ consists largely of undigested microbial protein arising from the rumen and hindgut.

2. The variation in biological value with the nature of the feed, which was recognised in ARC (1965), was probably related to the degree of degradation of dietary protein in the rumen, and thus to the extent to which amino acids from microbial protein were supplemented with those from dietary protein that escaped degradation in the rumen (undegraded dietary protein).

3. There was insufficient appreciation of the fact that a balanced fermentation, dependent on the relative amounts of degraded $\mathrm{N}$ and readily fermentable carbohydrate in the rumen is essential for maximum voluntary intake of feed and efficiency of feed utilisation. The possibility of reduced fermentation was recognised in ARC (1965) where to ensure that microbial synthesis was not limited by the supply of $\mathrm{N}$, a lower limit of $90 \mathrm{~g}$ crude protein $/ \mathrm{kg}$ dietary dry matter was set.

4. It was not possible to differentiate between absorption of amino acid $\mathrm{N}$, ammonia $\mathrm{N}$ or other forms of non-amino acid $\mathrm{N}$, such as nucleic acids, or to allow for differences in response according to the form in wich the $\mathrm{N}$ was given.

5. No attempt was made to relate the $\mathbf{N}$ requirements to total energy intake and energy concentration in the diet in any systematic way.

\section{Standards for ruminant cattle based on the concept of rumen degradable and undegraded dietary protein}

To overcome the criticisms given above, a system which takes into account contributions from microbial protein and undegraded dietary protein has been proposed (Roy et al., 1977). It is based on an estimate of the total amino acid N absorbed from the small intestine, and the efficiency of its utilisation for tissue synthesis and maintenance at the energy input and concentration in the diet necessary for a particular level of production.

The first step is to calculate the amount of amino acid $\mathrm{N}$ of microbial origin that can be retained in the body for tissue synthesis when the maximal rate of rumen fermentation for a particular energy input is achieved. This amount 
of amino acid $\mathrm{N}$ is then compared with the total tissue needs at the particular level of energy input, as follows :

(a) If the amount of microbial amino acid $\mathrm{N}$ available to the tissues is greater than the tissue needs, the $\mathrm{N}$ requirement of the animal is the amount of degraded $\mathrm{N}$ needed by the rumen micro-organisms. Thus, the rumen need for $\mathrm{N}$ is the minimum $\mathrm{N}$ requirement for the animal at a particular energy intake, even if amino acid $\mathrm{N}$ arising from the microbial protein is in excess of the amino acid $\mathrm{N}$ requirements of the tissues.

(b) If the microbial amino acid $\mathrm{N}$ is less than the tissue needs, then the deficit must be supplied by amino acid $\mathrm{N}$ from undegraded dietary protein. follows :

A summary of the method which is based on three linear equations is as

1. The amount of rumen degradable protein $(\mathrm{RDP})(\mathrm{N} \times 6.25)$ that is required for maximal rate of digestion and microbial protein synthesis in the rumen at a given energy input is estimated.

$\mathrm{RDP}$ requirement $(\mathrm{g} / \mathrm{d})=7.8 \mathrm{ME}(\mathrm{MJ} / \mathrm{d}) \ldots \ldots \ldots \ldots \ldots$

This equation has been obtained as follows:

$\mathrm{RDP}$ requirement $=6.25\left(\mathrm{ME} \times \frac{1}{(0.82 \times 19.0)} \times 0.65 \times 1.0 \times 30\right)$

where (a) $\mathrm{ME}=$ metabolisable energy intake $(\mathrm{MJ} / \mathrm{d})$.

(b) $\frac{1}{(0.82 \times 19.0)}=$ factor to convert ME to digestible organic matter $\left(D_{0}\right)$ on the assumption that 18 per cent of apparently digested energy is lost in $\mathrm{CH}_{4}$ and urine and that $1 \mathrm{~kg} \mathrm{D} o=19.0 \mathrm{MJ}$ digestible energy.

(c) $0.65=$ proportion of $\mathrm{D}_{0}$ that is apparently digested in the rumen.

(d) $1.0=$ efficiency of conversion of degraded $\mathrm{N}$ to microbial $\mathrm{N}$ (except for urea or similar NPN sources, see below).

(e) $30=$ microbial $\mathrm{N}$ yield $(\mathrm{g} / \mathrm{kg} \mathrm{D}$ apparently digested in the rumen).

In compilation of these equations, average values for a number of factors have been used, for which the supporting evidence is sometimes meagre and the individual values often very variable. For instance, ground and pelleted forages and uncooked maize probably have lower values than 0.65 for the proportion of apparently digested organic matter that is apparently digested in the rumen. Similarly there are wide differences in the value for microbial protein yield due both to diets and to the techniques used in its measurement (SIDDONS et al., 1979). Efficiency of conversion of degraded dietary protein $\mathrm{N}$ to microbial $\mathrm{N}$ is considered to have a value of unity on the basis that any inefficiency in the incorporation of degraded $\mathrm{N}$ into microbial $\mathrm{N}$, when $\mathrm{N}$ intake is just limiting, will be compensated by the recycling of $\mathrm{N}$ into the rumen.

Since absolute ME requirement $(\mathrm{MJ} / \mathrm{d})$ of cattle varies for different liveweights, sex, breed, form or level of production and the type of ration, it follows 
that the absolute requirements of RDP vary similarly. In contrast, the required concentration of RDP in the dry matter of a diet ( $\mathrm{g} / \mathrm{kg}$ dry matter) varies only with the metabolisability of the gross energy in the diet.

Thus $\mathrm{RDP} / \mathrm{I}_{\mathrm{T}}=7.8 \mathrm{ME} / \mathrm{I}_{\mathrm{T}}$

where $\mathrm{I}_{\mathrm{T}}=$ intake of dry matter $(\mathrm{kg})$

and if the heat of combustion of dry matter is accepted as $18.4 \mathrm{MJ} / \mathrm{kg}$, then:

$\mathrm{RDP} / \mathrm{I}_{\mathbf{T}}=144 q$

where $q=$ metabolisability of the gross energy.

2. The amount of amino acid $\mathbf{N} \times 6.25$ that is absorbed and retained (TMP) from the microbial protein synthesised in the rumen is estimated :

$\operatorname{TMP}(\mathrm{g} / \mathrm{d})=3.3 \mathrm{ME}(\mathrm{MJ} / \mathrm{d}) \ldots \ldots \ldots \ldots$

This equation has been obtained as follows :

$\mathrm{TMP}=\mathrm{RDP}$ requirement $\times 0.80 \times 0.70 \times 0.75$

where (a) $0.80=$ proportion of total microbial $\mathrm{N}$ that is amino acid $\mathrm{N}$.

(b) $0.70=$ apparent absorption in the small intestine of amino acid $\mathrm{N}$ from microbial protein.

(c) $0.75=$ efficiency of utilisation of absorbed amino acid $\mathrm{N}$ for tissue synthesis and the inevitable endogenous loss of $\mathrm{N}$ in the urine.

3. The amount of amino acid $\mathrm{N} \times 6.25$ retained from microbial protein is compared with the tissue requirement of amino acid $\mathrm{N} \times 6.25$ for the particular productive process.

(a) If TMP is in excess of the tissue requirement, the RDP requirement is the minimum protein requirement of the animal.

(b) If TMP is less than the tissue requirements, the deficit must be provided by amino acid $\mathrm{N}$ from undegraded dietary protein (UDP).

UDP requirement $(\mathrm{g} / \mathrm{d})=1.91 \mathrm{TP}-6.25 \mathrm{ME}$

where $\mathrm{TP}=$ sum of amino acid $\mathrm{N} \times 6.25$ retained in body tissue of the animal together with endogenous urinary $\mathrm{N} \times 6.25$ excretion and $\mathrm{N}$ loss in hair and scurf $\times 6.25(\mathrm{~g} / \mathrm{d})$.

This equation has been obtained from :

$$
\mathrm{UDP} \text { requirement }=\frac{\mathrm{TP}-\mathrm{TMP}}{0.75 \times 0.70}
$$

where (a) TMP $=3.3 \mathrm{ME}$ (equation 2).

(b) $0.75=$ efficiency of utilisation of absorbed amino acid $\mathrm{N}$.

(c) $0.70=$ apparent absorption of amino acids in the small intestine.

Although there are probably differences between microbial and dietary protein and also between various protein sources both in the apparent absorption of amino acids from the small intestine and in the efficiency of their utilisation, it has not been possible to quantify them. For instance, excessive heat or chemical treatment intended to protect protein sources from degradation in the rumen may result in a marked reduction in digestibility of protein in the small intestine. Similarly, although a value of 0.75 for efficiency of utilisation is considered appropriate for $\mathrm{N}$-limiting diets, it seems probable that a somewhat lower value may be appropriate for the efficiency of utilisation of microbial protein, because 
the concentration of sulphur-containing amino acids may be lower in microbial protein than in undegraded dietary protein. The higher efficiency of utilisation of some dietary protein sources, such as fishmeal, although possibly accounted for by differences in the extent of their degradation in the rumen, may also be related to their more suitable amino acid composition.

The tissue protein (TP) requirement is the sum of :

1. Endogenous urinary $\mathrm{N} \times 6.25(\mathrm{~g} / \mathrm{d})=6.25\left(5.9206 \log _{10} \mathrm{~W}-6.76\right)$.

2. Dermal $\mathrm{N}$ loss $\times 6.25(\mathrm{~g} / \mathrm{d})=6.25\left(0.018 \mathrm{~W}^{0.75}\right)$.

3. Protein in weight gain $(\mathrm{g} / \mathrm{d})=\Delta \mathrm{W}\left(168.07-0.16869 \mathrm{~W}+0.0001633 \mathrm{~W}^{2}\right)$ $(1.12-0.1223 \Delta \mathrm{W})$ for castrates of medium-sized breeds, where $\mathrm{W}=$ liveweight $(\mathrm{kg})$ and $\Delta \mathrm{W}=$ liveweight gain $(\mathrm{kg} / \mathrm{d})$.

The estimates for protein concentration in weight gain are increased by 10 per cent for bulls and by a further 10 per cent for large-sized breeds and reduced by 10 per cent for heifers and by a further 10 per cent for small-sized breeds (ARC, 1980).

The sum of the RDP and UDP requirements is the minimum amount of protein needed by the animal, if the degradability of the dietary protein is such as to supply exactly the RDP and UDP requirement i.e. the optimum degradability.

The formulation of diets to meet these requirements necessitates a knowledge of the degradability of the various constituents, so that RDP and UDP can be matched to the requirement of the animal.

Dietary ingredients have been allocated to three main degradability classes, Class A, 0.80 ; Class B, 0.60 ; and Class C, 0.40. For instance hay, grass silage, cereals, other than maize, and groundnut meal are allocated to Class A ; maize silage, maize and cooked soyabean meal to Class B, and ground and pelleted artificially dried legumes and fishmeal to Class C. However, these values are likely to be affected not only by the processing treatment but also by such factors as the level of intake and the roughage : concentrate ratio of the ration.

If in a proposed ration there is a deficit of RDP only, this may be overcome by inclusion of a source of non-protein $\mathrm{N}$. Non-protein $\mathrm{N}$, other than preformed amino acid and peptide $\mathbf{N}$, is assumed to be associated with an efficiency of conversion of degraded $\mathrm{N}$ to microbial $\mathrm{N}$ of 0.80 rather than 1.0.

$$
\text { Thus the weight of urea } \begin{aligned}
(\mathrm{g}) & =\frac{\text { deficit of RDP }}{6.25 \times 0.80 \times 0.46} \\
& =\frac{\text { deficit of RDP }}{2.30}
\end{aligned}
$$

where $0.46=\mathrm{N}$ content of urea $(\mathrm{g} / \mathrm{g})$

and $0.80=$ efficiency of conversion of urea $\mathrm{N}$ to microbial $\mathrm{N}$.

When urea is being used, the ration should be supplemented with $0.07 \mathrm{~g}$ sulphur $/ \mathrm{gN}$ in urea e.g. $0.15 \mathrm{~g}$ anhydrous sodium sulphate/g urea.

For a $300 \mathrm{~kg}$ steer of a medium-sized breed gaining weight at $1.25 \mathrm{~kg} / \mathrm{d}$, the daily requirement of $\mathrm{ME}$ is $79.6 \mathrm{MJ}$ at a metabolisability of gross energy of 0.60 , the requirement of RDP is $621 \mathrm{~g}$ but no UDP is required, since the amount of TMP more than covers tissue protein (TP) requirements. Thus the optimum degradability is 1.0 and the minimum protein requirement, in $7.24 \mathrm{~kg}$ dry matter, is $86 \mathrm{~g} / \mathrm{kg}$ dry matter. 
A ration of rolled barley $(4.2 \mathrm{~kg}$ dry matter) and barley straw $(3.0 \mathrm{~kg}$ dry matter), which would supply the energy needs, has a protein content of $79 \mathrm{~g} / \mathrm{kg}$ dry matter and an estimated degradability of 0.80 so the ration contains only $63 \mathrm{~g} \mathrm{RDP} / \mathrm{kg}$ dry matter. If the diet is supplemented with conventional protein that also has a degradability of 0.80 , then $\frac{86}{0.80}=108 \mathrm{~g}$ protein $/ \mathrm{kg}$ dry matter will be needed in the ration. If urea is used to make up the deficiency of RDP and thereby avoiding wastage of UDP, a diet containing $101 \mathrm{~g}$ protein $/ \mathrm{kg}$ dry matter at an overall degradability of 0.84 will supply the needs of the animal (Roy et al., 1977).

\section{Protein standards for pre-ruminant cattle}

In calculating the protein requirements of pre-ruminant cattle, the following formula has been used :

Protein requirement $(\mathrm{g} / \mathrm{d})=\frac{\mathrm{TP}}{d_{\mathrm{N}} \times k_{\mathrm{N}(\mathrm{U})}}$

where $\mathbf{T P}=$ tissue protein $(\mathrm{g} / \mathrm{d})$ as defined for ruminant cattle.

$d_{\mathrm{N}}=$ apparent digestibility of $\mathrm{N}$ (0.92 for milk protein; lower values for non-milk protein).

$k_{\mathrm{N}(\mathrm{U})}=$ efficiency of utilisation of absorbed $\mathrm{N}(0.80$ for milk protein, possbily lower value for some non-milk protein sources).

It is recognised that for the pre-ruminant, the method used in ARC (1965) which involved the use of true digestibility of $\mathbf{N}$ and made allowance for metabolic faecal $\mathrm{N}$, has greater theoretical validity than the use of apparent digestibility of $\mathrm{N}$ and the ignoring of metabolic faecal $\mathrm{N}$. However, for consistency with the approach taken for the ruminant animal and because apparent digestibility of different protein sources can be easily measured, the procedure given above has been adopted (ARC, 1980).

\section{Validity of the proposed system}

A survey has been made of feeding and balance trials carried out in the UK since 1963, in which protein intake appears to be limiting growth and in which energy and protein intakes for growth at particular liveweights have been measured. These protein intakes, which are treatment mean values, are shown in Figure 1 for cattle of $50-100 \mathrm{~kg}$ and $200-300 \mathrm{~kg}$ liveweight. The RDP and where necessary the UDP requirements are shown at the mean liveweight of the animals and at the mean metabolisability of the gross energy of the dietary treatments. Where RDP is sufficient to cover the needs of the animal for a particular growth rate, the minimum crude protein required in the diet with a degradability of 0.80 is also shown. The proposed system seems to give results which agree with those of practical trials.

The proposed system may also be compared with the present sysîem used by the UK advisory service. Total dietary protein concentration for a weight gain of $1.0 \mathrm{~kg} / \mathrm{d}$ for liveweights from $100-500 \mathrm{~kg}$ have been calculated from the recommended digestible crude protein concentrations based on the amounts 
of digestible protein required (RoY, 1959), and dry matter intakes (MINISTRY OF AGRICULTURE, FISHERIES AND FOOD, 1975) using assumed apparent digestibility values declining from 0.75 at $100 \mathrm{~kg}$ liveweight to 0.65 at $500 \mathrm{~kg}$ liveweight. These values for the present system are shown in Figure 2 where they may be compared with the total protein concentrations and degradabilities required in the proposed system for bulls of large breed size given diets of metabolisability
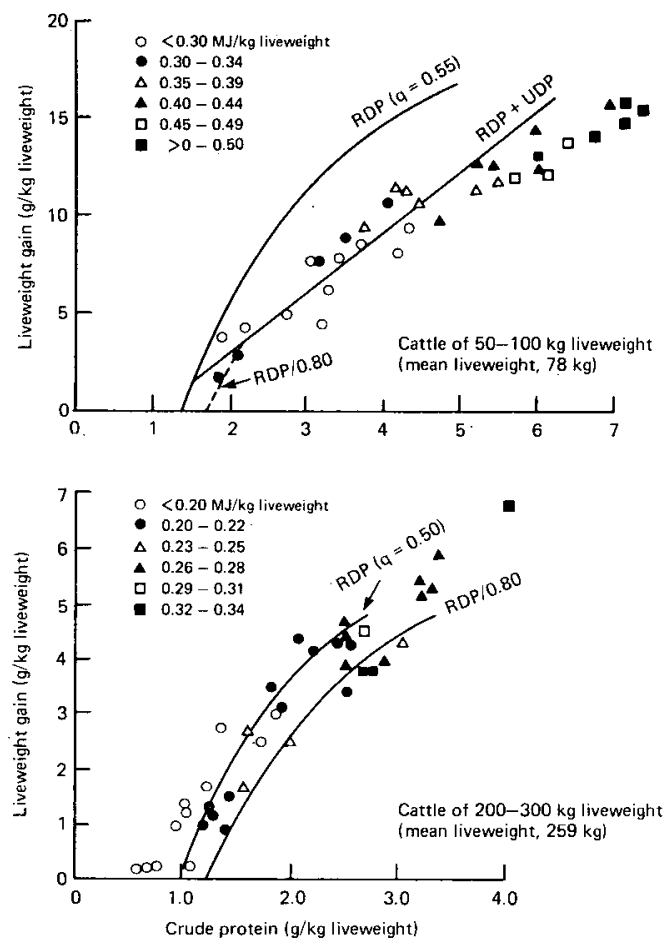

Fig. 1. - Comparison of proposed protein requirements with results from practical trials in which protein intake appeared to be limiting performance. (Each value is a treatment mean).

of energy of 0.5 and 0.7 . For situations where no UDP is required i.e. a degradability of 1.0, dietary protein concentrations are also given for a degradability of 0.80 . When the requirements of "available protein" (ARC, 1965) are converted to crude protein concentrations using the digestibilities and dry matter intake values given above, they are very similar to the proposed values for a metabolisability of energy of 0.5 .

It would appear that, in comparison with the proposed standards, the present standards used by the advisory service tend to underestimate the requirement in situations where high-concentrate diets are being used and to overestimate the requirements for poorer quality diets. 


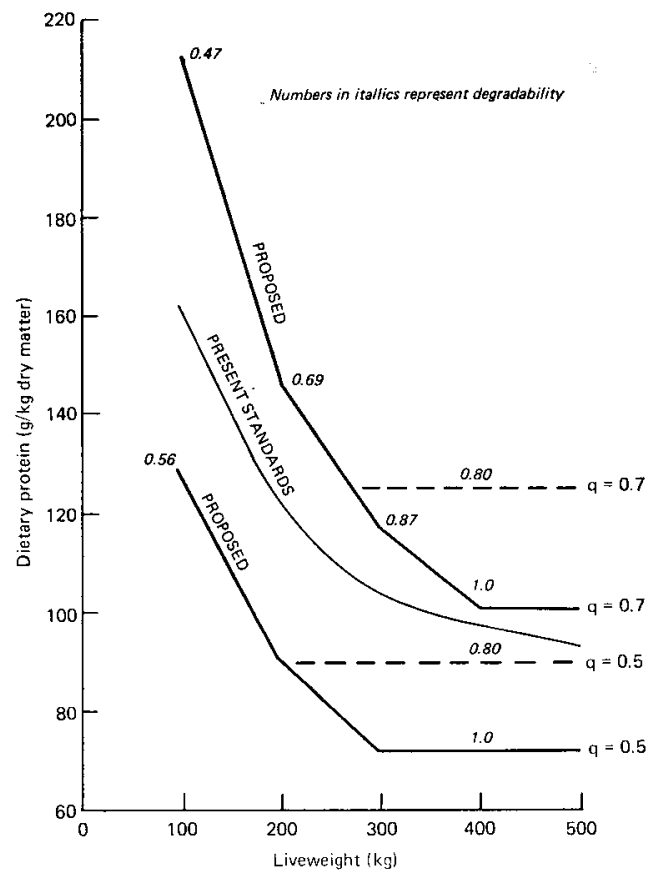

FIG. 2. - Comparison of the concentration of dietary protein for $1 \mathrm{~kg}$ gain/d in the present standards used by the UK advisory service, with those proposed in the new ARC system for bulls of large breed size given diets of metabolisability $(q)$ of 0.5 and 0.7 .

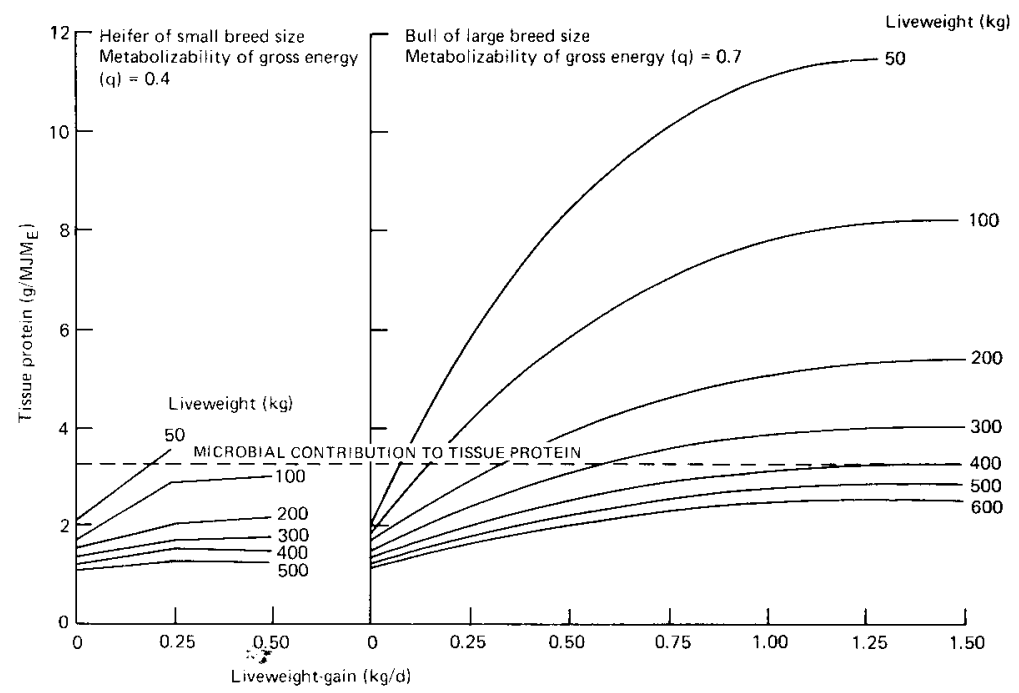

FIG. 3. - Comparison of the tissue protein requirement per unit of ME for heifers of small breed size given a diet of metabolisability of gross energy of 0.4 with that of a bull of large breed size given a diet of metabolisability of 0.7 . The microbial contri. bution to tissue protein is also shown. 


\section{Some implications of the proposed system}

From Figure 3 it can be seen that the microbial contribution to tissue protein in relation to total tissue protein requirement is lowest for bulls of large breed size having a high concentrate diet $(q=0.7)$ and greatest for heifers of small breed size on a poor quality high roughage diet $(q=0.4)$; in the latter situation RDP can be the sole form of protein for growth rates of up to $0.50 \mathrm{~kg} / \mathrm{d}$.

Even with rations of the same metabolisability of the gross energy e.g. $q=0.5$, it would appear that breeds of small size would need less UDP to achieve a saleable carcase than would breeds of large size. This is shown in Figure 4, where the microbial contribution to tissue protein is shown for steers of small and large breeds. With the assumption of a birth weight of $27 \mathrm{~kg}$ and a final liveweight of $400 \mathrm{~kg}$ for the small breed $(0.69 \mathrm{~kg} / \mathrm{d})$ and a birth weight of $48 \mathrm{~kg}$ and a final liveweight of $520 \mathrm{~kg}$ for the large breed $(0.87 \mathrm{~kg} / \mathrm{d})$ at 18 months of age, microbial protein could supply 67 per cent of the requirements of the small breed (above $150 \mathrm{~kg}$ liveweight) but only 57 per cent of the requirements of the large breed (above $250 \mathrm{~kg}$ liveweight).

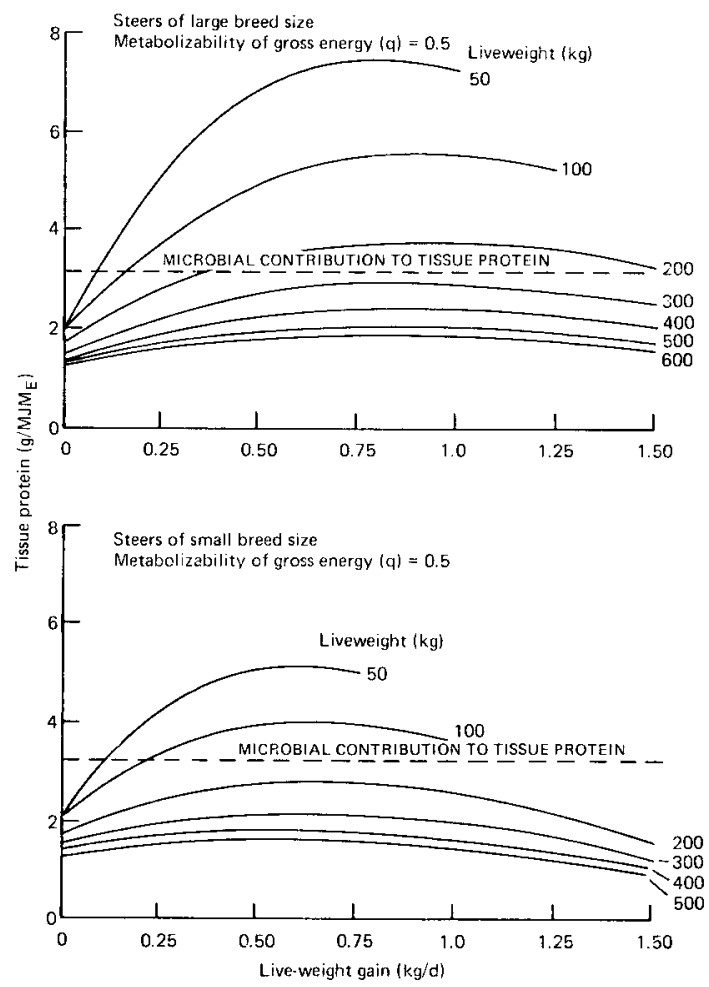

FIG. 4. - Comparison of the tissue protein requirement per unit of $M E$ of steers of large and small breed size given a diet of metabolisability $(q)$ of 0.5 . The microbial contribution to tissue protein is also shown. 


\section{Conclusions}

The proposed system should be regarded as a framework for future research efforts and as a mean of focusing attention on those factors for which additional data are required. The most critical factor which will limit full exploitation of the system is the estimation not only of average values for degradabilities of particular ration ingredients, but also those for different batches of the same ingredients and making allowances for the other variables, especially those within the rumen, that may affect degradability. Probably one of the most important benefits of the new system for beef production is that it enables the producer to predict the conditions under which a response may be obtained from non-protein $\mathrm{N}$.

\section{References}

Agricultural Research Council, 1965. Nutrient requirements of farm livestock. No. 2. Ruminants. Technical reviews and summaries. London, HMSO.

Agricultural Research Council, 1980. Nutrient requirements of farm livestock. No. 2. Ruminants. (In press).

Bailey G.L., Broster W.H., 1957. Experiments on the nutrition of the dairy heifer. Protein requirements of yearling stock. J. agric. sci., Camb., 49, 435.

Blaxter K.L., Mitchell H.H., 1948. The factorisation of the protein requirements of ruminants and of the protein values of feeds with particular reference to the significance of the metabolic faecal nitrogen. J. Anim. Sci., 7, 351.

BlaXTER K.L., WoOD W.A., 1951. The nutrition of the Ayrshire calf 4. Some factors affecting the biological value of protein determined by nitrogen-balance methods. $B r . J$. Nutri., 5, 55 .

Brisson G.J., Cunningham H.M., Haskell S.R., 1957. The protein and energy requirements of young dairy calves, J. Anim. Sci., 37, 157.

Evans R.E., 1960. Rations for livestock. 15th Edition. Bull. Minst. Agri. Fish. Fd., No. 48, London. HMSO.

Lofgreen G.P., Loosli J.K., Maynard L.A., 1951. Comparative study of conventional protein allowance and theoretical requirements of growing Holstein heifers. J. Anim. Sci., 10, 171.

Ministry of Agriculture and Fisheries, 1925. Report of Departemental Committee on Rationing of Dairy Cows. London, HMSO.

Ministry of Agriculture, Fisheries and Food, 1975. Energy allowances and feeding systems for ruminants. Tech. Bull. No. 33. London, HMSO.

Mitchell H.H.. 1929. The minimum protein requirement of cattle. Bull. Natn. Res. Coun. Wash., No. 67.

Roy J.H.B., 1959. Scientific Principles of Feeding Farm Livestock. Proceedings of Brighton Conference, p. 48. London, Farmer et Stockbreeder Publications Ltd.

Roy J.H.B., Balch C.C., Miller E.L., Orskov E.R., Smith R.H., 1977. Calculation of the N-requirement for ruminants from nitrogen metabolism studies. Proc. 2nd Int. Symp. Protein metabolism and Nutrition, p. 126. Wageningen.

Siddons R.C., Beever D.E., Nolan J.V., MCAllan A.B., Macrae J.C., 1979. Estimate of microbial protein in duodenal digesta. Ann. Rech. Vet., 10, 286. 